\title{
First resolution of flow through the Hunter Channel in the South Atlantic
}

\author{
Kevin Speer ${ }^{a}$, Walter Zenk ${ }^{a}$, Gerold Siedler ${ }^{a}$, Jürgen Pätzold ${ }^{b}$ \\ and Clemens Heidland ${ }^{\mathrm{c}}$ \\ a Institut für Meereskunde, Düsternbrooker Weg 20, D-2300 Kiel 1, Germany \\ ${ }^{b}$ Unwersitat Bremen, Fachbereich 5, Geowissenschaften 1, Postfach 330440, D-2800 Bremen 33, Germany \\ ${ }^{c}$ Alfred Wegener Institut, Postfach 1201 61, D-2850 Bremerhaven 12, Germany \\ Recerved June 18, 1992; revision accepted July 6, 1992
}

\begin{abstract}
Dense Antarctic Bottom Water formed around the contınent of Antarctica spreads northward in the Atlantic underneath North Atlantic Deep Water, gradually mixıng and upwelling into it. This Antarctıc Water forms a significant element of the meridional circulation in both directions: northward as bottom water and southward as deep water. It is important to determine the strength of each component to assess its role in ocean circulation. Such measurements are useful when made in constricted pathways because any flow is more clearly defined. A new set of fine-resolution hydrograhic measurements in the Hunter Channel of the South Atlantic Ocean has been obtained, which allow the geostrophic bottom flow there to be estımated for the first tıme The northward flow through the Hunter Channel of water cooler than $2^{\circ} \mathrm{C}$ is thus estimated to be $0.7 \times 10^{6} \mathrm{~m}^{3} \mathrm{~s}^{-1}$.
\end{abstract}

The source of the densest water for most of the Atlantic Ocean is the Weddell Sea, south of South America. This is the largest embayment of the Antarctic continent, and the ocean is cooled there to such a degree that water dense enough to sink to the bottom is produced [1]. This Antarctic Bottom Water flows north and enters the Atlantic at its southwestern corner, where it fills the Argentine Basin up to the level of the surrounding sills. Initially close to the freezing point, the bottom water mixes along its route with overlying water and is diluted, becoming warmer and generally loosing the tracer characteristics it acquired in the Weddell Sea. This mixture forms a layer roughly $1 \mathrm{~km}$ thick covering virtually the entire Atlantic Ocean, but in order to penetrate north away from its source it must cross a number of ridges that block its path.

The most important barrier to the northward progress of bottom water in the Atlantic is the system consisting of the Rio Grande Rise and

Correspondence to: $K$. Speer, Laboratorre de Physique des Océans, IFREMER, B.P. 70, 29280 Plouzané, France.
Walvis Ridge near $30^{\circ} \mathrm{S}$; these two ridges block flow on the western and eastern side of the Mid-Atlantic Ridge respectively. While the Walvis Ridge prevents a significant flow of Antarctic Bottom Water from continuing north in the eastern South Atlantic Ocean [2], a strong flow of bottom water does cross the Rio Grande Rise. The primary pathway across this barrier has long been known to be the Vema Channel [3] (Fig. 1).

This situation has attracted several research programmes dedicated to the Vema Channel [46], and direct current measurements [6] indicate a mean transport over one year of $4 \pm 0.4 \times 10^{6} \mathrm{~m}^{3}$ $\mathrm{s}^{-1}$ of bottom water through this channel. The transport depends, of course, on how one defines bottom water, but it is observed that the velocity of the flow decreases to zero (on average) at a level above the bottom where the potential temperature ${ }^{1}$ is about $2^{\circ} \mathrm{C}$, and it is common to

\footnotetext{
The temperature that a parcel of seawater has if raised to the surface adiabatically. The in-situ temperature is higher, at about $2.3^{\circ} \mathrm{C}$.
} 


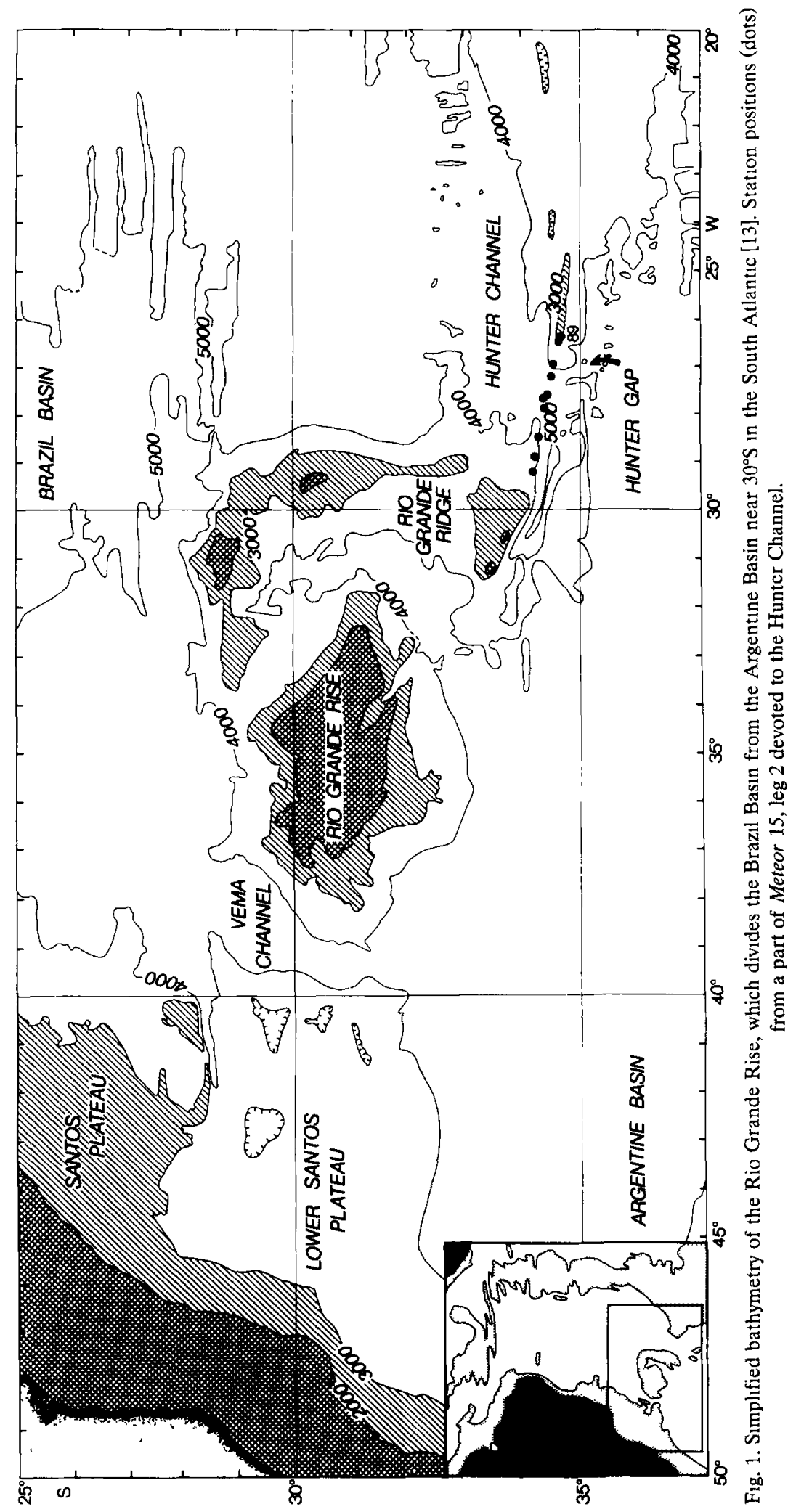


make transport estimates taking this isotherm as the top of the bottom layer. The typical speed encountered at the bottom of the Vema Channel is $10 \mathrm{~cm} \mathrm{~s}^{-1}$, with occasional values higher than $30 \mathrm{~cm} \mathrm{~s}^{-1}$; speeds decrease to zero roughly $1 \mathrm{~km}$ above the bottom.

On the other hand, higher bottom temperatures on the northern, Brazil Basin side of the Hunter Channel have led Wüst [3] and subsequent investigators to the conclusion that the passage is shallow and flow is inhibited. Past evidence for flow of bottom water through the Hunter Channel has come essentially from geological studies. The discovery of diatoms which survive in Antarctic Bottom Water in the Hunter Channel gave a geological impetus to studies there, suggesting that this water did cross the rise in the past and may be doing so presently [7].

The first hydrographic measurements with sufficient horizontal resolution to constitute a true section across the Hunter Channel were made in 1959 , for a total of seven stations along $32^{\circ} \mathrm{S}$, between the Rio Grande Ridge and the MidAtlantic Ridge [8]. No features suggesting deep. flow stood out, but the topography is rough in the region and the horizontal and vertical resolution (discrete water samples with $200-400 \mathrm{~m}$ vertical spacing) were still rather coarse for measuring weak flow near the bottom. The horizontal resolution near the western boundary of the Hunter Channel, the Rio Grande Ridge, was later improved somewhat [9], but still no identifying structure became apparent. A recent estimate of deep transport through the Hunter Channel is $1.8 \times 10^{6} \mathrm{~m}^{3} \mathrm{~s}^{-1}$, based on these older data but assuming a weak northward bottom flow, partly for the purpose of achieving an overall mass balance in the region [10].

As part of the World Ocean Circulation Experiment a programme was designed to measure the total source of deep water to the Brazil Basin, including inflow across the Rio Grande Rise and outflow at the equator [11]. In the framework of this programme a hydrographic section was occupied at the Hunter Channel by the F.S. Meteor (cruise 15, leg 2) (Fig. 1). A total of ten CTD stations with nearly continuous vertical coverage were placed across a narrow part of the channel between two ridges. The $200 \mathrm{~km}$ width of the channel is roughly ten times that of the Vema

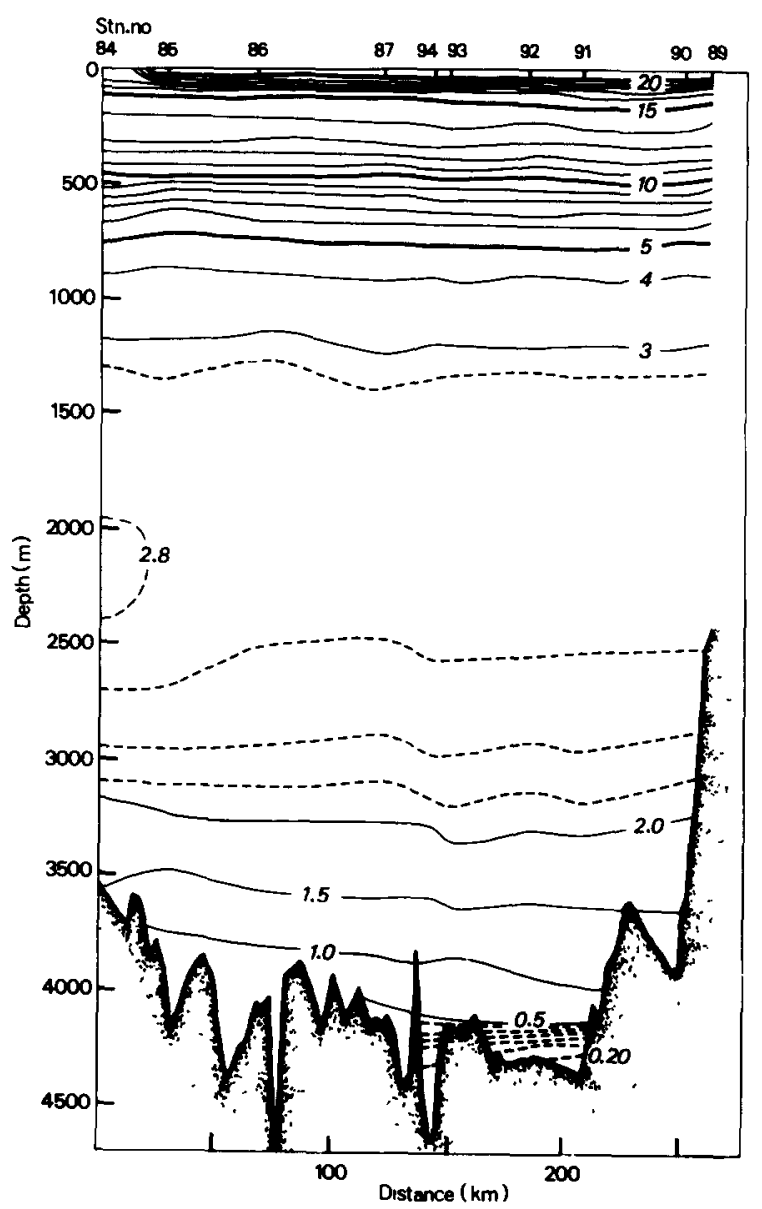

Fig. 2. Profile of potential temperature $\left({ }^{\circ} \mathrm{C}\right)$ across the Hunter Channel obtained during Meteor crusse 15 (February, 1991). The Hunter Gap is the broad valley in the $150-220 \mathrm{~km}$ distance range.

Channel to the west-an important point because spreading a mass source over a broad area weakens the flow and tends to mask any dynamic signal such as sloping isotherms. The Hunter Channel section is just north of a deep fracture (depths greater than $5000 \mathrm{~m}$ ) which appears to be an isolated piece of a larger scale fracture zone emanating from the Mid-Atlantic Ridge.

The coldest bottom water was found in what is evidently the northward extension of the Hunter Gap [12] (Fig. 2, between distances of 150 and $220 \mathrm{~km}$ ). Values below $0.2^{\circ} \mathrm{C}$ occurred on the eastern side of the gap, which was reminiscent of a similar, but more pronounced pattern of eastern intensification of tracer characteristics in the Vema Channel $[5,6]$. Water of this temperature 
can only have come from south of the section, as all other observations show higher bottom temperature to the north. At somewhat shallower depths and for temperatures of between about $0.5^{\circ} \mathrm{C}$ and $2^{\circ} \mathrm{C}$, the coolest water is at the western boundary of the section and isotherms slope downward to the east, indicating the northward flow of bottom water relative to the warmer surface. Taking the flow to be zero at the $2^{\circ} \mathrm{C}$ surface, the bottom (geostrophic) velocities were typically $1-2 \mathrm{~cm} \mathrm{~s}^{-1}$, and the total transport below $2^{\circ} \mathrm{C}$ was $0.7 \times 10^{6} \mathrm{~m}^{3} \mathrm{~s}^{-1}$. This figure includes transport contributions below the deepest common level of a given station pair, obtained by multiplying the deepest velocity by the area between the stations. Despite the relatively high horizontal resolution of the new section, this contribution amounted to about $20 \%$, suggesting that some bottom intensified flow may have been missed. With even higher resolution perhaps the transport estimate would be raised closer to $1 \times$ $10^{6} \mathrm{~m}^{3} \mathrm{~s}^{-1}$.

Although the dominant source of error is probably still related to horizontal resolution, and therefore difficult to estimate, the error related to the choice of reference level may be shown by choosing nearby levels and performing the calculation again. Three constant density surfaces were chosen, both to verify that the same result obtains for this choice, and because at higher temperatures there is an extreme, making temperature unsuitable as a reference surface. The shallow surface was on the potential density anomaly surface $\sigma_{4}=45.80 \mathrm{~kg} \mathrm{~m}^{-3}$, near $2.4^{\circ} \mathrm{C}$, which gave $0.8 \times 10^{6} \mathrm{~m}^{3} \mathrm{~s}^{-1}$. The choice $\sigma_{4}=45.85 \mathrm{~kg} \mathrm{~m}^{-3}$ is close to $2.0^{\circ} \mathrm{C}$, and produced the figure of $0.7 \times$ $10^{6} \mathrm{~m}^{3} \mathrm{~s}^{-1}$. Finally, a deeper surface at $\sigma_{4}=45.90$ $\mathrm{kg} \mathrm{m}^{-3}$, near $1.5^{\circ} \mathrm{C}$, is clearly within the region of flow and thus produced the low result $0.3 \times 10^{6}$ $\mathrm{m}^{3} \mathrm{~s}^{-1}$. Based on this moderate reference level dependence and on a standard deviation of $0.1 \times$ $10^{6} \mathrm{~m}^{3} \mathrm{~s}^{-1}$ for the set of transports at each station pair, the above transport estimate at $2^{\circ} \mathrm{C}$ is thought to be accurate to better than $50 \%$.

It is unlikely that significant bottom water flow was missed east of the section, because a broad ridge (or eastern continuation of the rise) shallower than $3600 \mathrm{~m}$ joins the Mid-Atlantic Ridge. Thus the connection between the Brazil Basin and Argentine Basin is closed off at this level, which is close to the $2^{\circ} \mathrm{C}$ zero velocity reference surface.

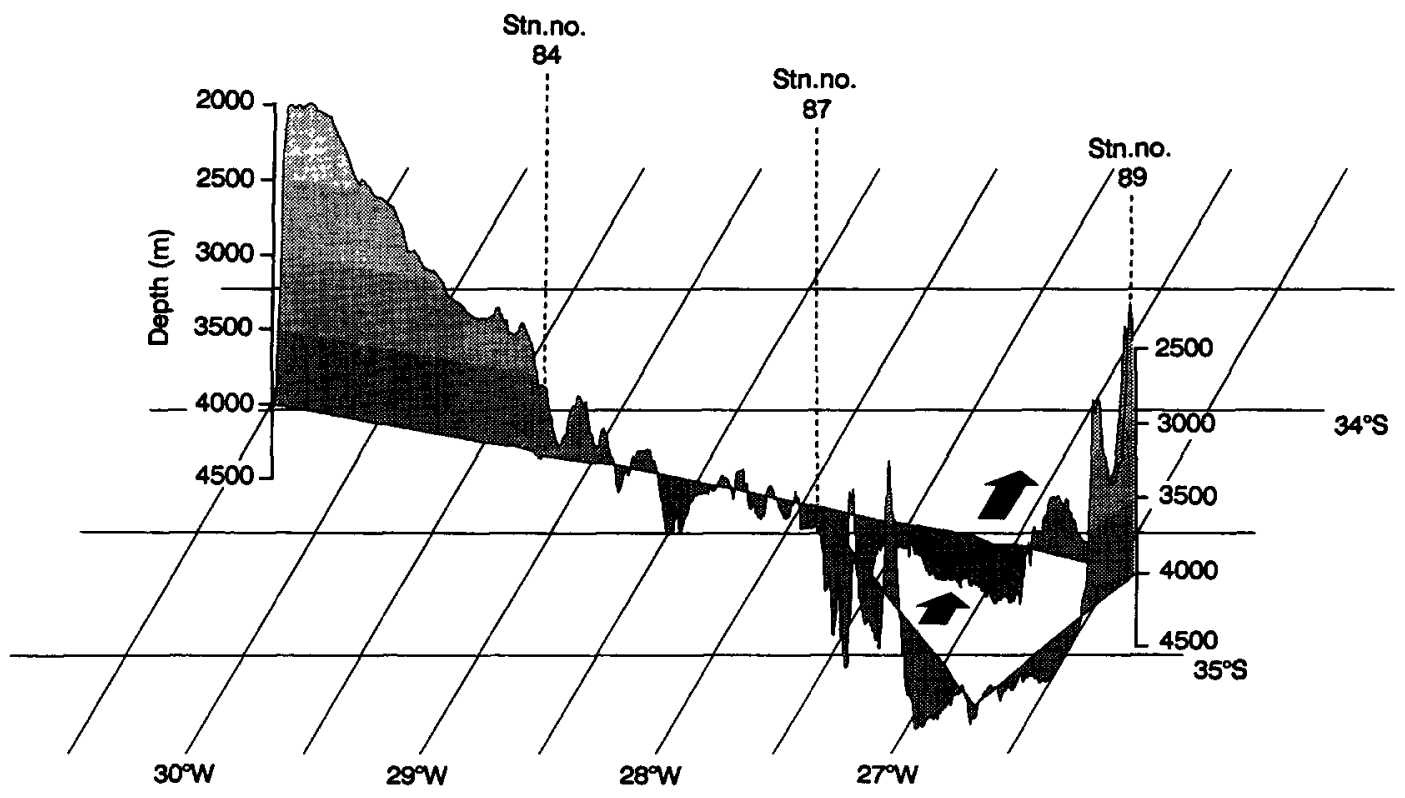

Fig. 3. Perspective plot of along-track bathymetry showing a part of the Rio Grande Ridge near $30^{\circ} \mathrm{W}$, another ridge near $26^{\circ} 30^{\prime} \mathrm{W}$ which continues to the east, and the Hunter Gap at $27^{\circ} \mathrm{W}$. The ship's track included an excursion to the south, forming a triangular route. 
The western boundary of the section is the Rio Grande Ridge, which blocks flow deeper than about $3400 \mathrm{~m}$ all the way to the Rio Grande Rise. Hydrographic measurements were also made in the Vema Channel to the west of the rise as part of the same programme, but on a separate expedition. These measurements verified that the earlier transport estimates through the Vema Channel still held at the time of the Hunter Channel observations.

The salinity field varies mainly in the vertical direction, and is correlated with temperature such that below about $3000 \mathrm{~m}$ isopycnals are parallel to isotherms. At the westernmost part of the section there is a temperature minimum near $1500 \mathrm{~m}$ and a temperature maximum near 2200 $\mathrm{m}$. This is a weaker, much reduced signal of the strong inversion at the western boundary, which is a well-known characteristic of the South Atlantic thermohaline structure [1]. It is produced by the presence of a cool, Antarctic Intermediate Water layer, fresh enough to be of lower density than the relatively salty North Atlantic Deep Water below it, despite the lower temperature.

The continuity of the Hunter Gap, at least as far north as our section, is clear from a profile of bathymetry along the cruise track at $27^{\circ} \mathrm{W}$ (Fig. 3 ). The narrower valleys just to the west are deeper, but do not seem to be an open, important pathway since temperatures are higher there (Fig. 2). More observations are needed to determine where these valleys begin and end, and their role (if any) in guiding the flow of bottom water.

The depth of the Hunter Gap is close to 4300 $\mathrm{m}$, which is only about $300 \mathrm{~m}$ shallower than the Vema Channel. Nevertheless this difference, together with the geostrophic depth increase of isotherms from west to east across the Vema Channel, eliminates water colder than $0^{\circ} \mathrm{C}$ from the Hunter Gap. Thus the average temperature of the bottom current is higher there, about $1^{\circ} \mathrm{C}$, versus a value closer to $0.5^{\circ} \mathrm{C}$ in the Vema Channel. The warmer Hunter Channel flow supplies water to the accordingly warmer southeastern corner of the Brazil Basin.

Our new, closely spaced CTD section across the Hunter Channel resolves the hydrographic structure of Antarctic Bottom Water there, and confirms the presence of northward flow. The geostrophic transport of this current, obtained from the new hydrographic data, is $0.7 \times 10^{6} \mathrm{~m}^{3}$ $\mathrm{s}^{-1}$, or roughly one-fifth of that entering the Brazil Basin through the Vema Channel. Although the contribution of this flow to the flux of heat across this latitude of the South Atlantic is small, it nevertheless plays a significant role in the mass balance of the bottom layer of the South Atlantic Ocean. The importance of this is that observations such as these usually provide the starting point for constructing dynamic models of the larger scale circulation in an ocean basin. The key physical processes in these models depend crucially on the vertical movement of water driven, in part, by the sources of mass. The Hunter Channel flow is an important component of the mass balance of the bottom water in the Brazil Basin (and, obviously, the Argentine Basin), and so it will be a necessary part of such dynamic studies.

\section{Acknowledgements}

We wish to acknowledge the help of Captain H. Bruns and the crew of the F.S. Meteor for a successful cruise and a winch that was in good working order. This work was supported by the Bundesminuster für Forschung und Technologie (contract 03F0535 A) and the Deutsche Forschungsgemeinschaft (contract 111/37-1).

\section{References}

1 B A. Warren, Deep circulation of the World Ocean, in: Evolution of Physical Oceanography, B.A. Warren and C. Wunsch, eds., pp 6-42, MIT Press, Cambridge, Mass., 1981

2 B.A. Warren and K.G. Speer, Deep circulation in the eastern South Atlantic Ocean. Deep-Sea Res. 38(Suppl.), 281-322, 1991 .

3 G. Wust, Schichtung und Zirkulation des Atlantischen Ozea Das Bodenwasser und die Gliederung der Atlantischen Tiefsee, in: Wissenschaftlıche Ergebnisse der Deutschen Atlantischen Expedition auf dem Forschungsund Vermessungsschiff Meteor 1925-1927, 6: 1, $106 \mathrm{pp}$, Teil, 1933.

$4 \mathrm{X}$ Le Pichon, M. Ewing and M. Truchau, Sedıment transport and distribution in the Argentine Basin. 2. Antarctic bottom current passage into the Brazil Basin, in: Physics and Chemistry of the Earth, L H. Ahrens, F Press, S.K. Runcorn and H.C Vrey, eds., pp. 31-48, Pergamon, 1971.

5 D. Johnson, S.E. McDowell, L.G. Sullıvan and P.E Biscaye, Abyssal hydrography, nephelometry, currents, and benthic boundary layer structure in the Vema Channel, J Geophys. Res. 8(1), 5771-5786, 1976. 
6 N. Hogg, P. Biscaye, W. Gardner and W.J. Schmitz, Jr., On the transport and modification of Antarctic Bottom Water in the Vema Channel, J. Mar. Res. 40(Suppl.), 231-263, 1982

7 L.H. Burckle and P.E. Biscaye, Sediment transport by Antarctic bottom water through the eastern Rio Grande Rise (abstract), Geol. Soc. Am. Abstr. Programs 3, 518519, 1971.

8 F.C. Fuglıster, Atlantıc Ocean Atlas of Temperature and Salinıty Profiles and Data from the Internatıonal Geophysical Year of 1957-1958 (Woods Hole Oceanographic Instıtution Atlas Series, 1), 209 pp., Woods Hole, Mass., 1960

9 J L. Reid, W.D Nowlin, Jr. and W.C. Patzert, On the characteristics and circulation of the southwestern Atlantic Ocean, J. Phys. Ocean. 7, 62-91, 1977.

10 J.L Reid, On the total geostrophic circulation of the South Atlantic Ocean. flow patterns, tracers, and transports, Prog. Oceanogr. 23, 149-244, 1989.

11 World Meteorological Organization, The deep basin experiment of the World Ocean Circulation Experiment. WCRP-11, In: World Ocean Circulation Experiment Implementation Plan, Geneva, 1988 (Unoff. Publ.).

12 N.Z Cherkıs, H.S Fleming and J M. Brozena, Bathymetry of the South Atlantic Ocean, $3^{\circ} \mathrm{S}-40^{\circ} \mathrm{S}$, Geol Soc. Am. Map Chart Ser. MCH 069, 1989. 